\title{
STUDI KOMPETENSI GURU PAUD DALAM MELAKUKAN ASESMEN PEMBELAJARAN DAN PERKEMBANGAN ANAK USIA DINI DI KOTA CIMAHI
}

\author{
Sri Nurhayati, M.Pd. dan Anita Rakhman, M.Pd \\ Sekolah Tinggi Ilmu Keguruan dan Pendidikan (STKIP) Siliwangi \\ e-mail: shrie33@yahoo.com, anitarakhman1@gmail.com
}

\begin{abstract}
Abstrak
Kompetensi asesmen pada pembelajaran dan perkembangan anak usia dini (AUD) merupakan kompetensi pedagogis yang sangat penting dimiliki para pendidik PAUD guna mengumpulkan dan menganalisis data mengenai perkembangan anak yang selanjutnya akan digunakan untuk kebutuhan pembelajaran di PAUD. Namun, pada kenyataannya kompetensi ini masih kurang dipahami dan dikuasai oleh para pendidik PAUD. Penelitian ini bertujuan memberikan gambaran tentang penguasaan kompetensi dalam asesmen pembelajaran dan perkembangan AUD sehingga memberikan hasil sebagai berikut: 1) kualifikasi akademik tidak mendukung penguasaan kompetensi asesmen pembelajaran dan perkembangan AUD; 2) pendidik PAUD yang diteliti sebanyak 25 orang $(89,3 \%)$ menyatakan mereka tahu kompetensi asesmen pembelajaran seperti yang disyaratkan oleh Permendiknas No. 58 Tahun 2009 dan hanya 3 orang (10,7\%) yang menyatakan tidak tahu; 3) pendidik PAUD yang diteliti sebagian besar $(96,5 \%)$ telah pernah mengikuti pelatihan asesmen pembelajaran, tetapi tingkat pemahaman dan penguasaan mereka tetap rendah; 4) terdapat fakta bahwa pemahaman dan penguasaan para pendidik terhadap asesmen pembelajaran tetap rendah meskipun mereka memenuhi kualifikasi akademik dan pernah mengikut pelatihan.
\end{abstract}

Kata kunci: kompetensi, asesmen, pembelajaran anak usia dini

\section{A STUDY OF EARLY CHILDHOODTEACHERS' COMPETENCY IN ASSESSING THE LEARNING AND DEVELOPMENT OF YOUNG CHILDREN IN CIMAHI}

\begin{abstract}
Competency in assessing young children's development and learning is an essential pedagogical competency to early childhood teachers in order to gather and analyze data about the children's development to be used for their learning in the early childhood education program. However, such competency is not either well-understood or sufficiently acquired yet by the early childhood teachers. This study focuses to describe the teachers' competency in assessing the development and learning of the young children and the results are as the following: 1) academic qualification didn't support the acquisition of competency in assessing the development and learning of the young children; 2$)$ twenty five $(89,3 \%)$ of the teachers in the study claimed that they knew the learning assessment competency as stated in Permendiknas No. 58 Tahun 2009 and only $3(10,7 \%)$ of the respondents stated that they didn't know the competency; 3 ) most $(96,5 \%)$ of the early childhood teachers in the study had taken part in a learning assessment training program, but their level of understanding and acquiring of the competency was still low; 4) there was a fact that the teachers' level of understanding and acquiring of the learning assessment competency remained low irrespective of their academic qualification or their involvement in a learning assessment training program.
\end{abstract}

Key words: competency, assessment, early childhood learning 


\section{PENDAHULUAN}

Jamaris (2006:164, dalam Yuliani, 2009: 2) menjelaskan bahwa asesmen pendidikan anak usia dini merupakan suatu proses kegiatan yang dilaksanakan bertujuan mengumpulkan data atau buktibukti tentang perkembangan dan hasil belajar yang berkaitan dengan perkembangan anak usia dini. Adapun Purwanto (1984:3, dalam Yuliani, 2009: 2) menjelaskan bahwa kegiatan penilaian merupakan suatu proses merencanakan, memperoleh data dan menyediakan informasi yang diperlukan untuk membuat alternatif-alternatif untuk mengambil keputusan.

Salah satu elemen yang berpengaruh terhadap asesmen bagi pendidikan anak usia dini adalah pendidik anak usia dini (Essa, 2003; Wortham, 2006). Kathleen Tarrant (2013: 1) dalam artikel penelitian yang berjudul "Building the Pipeline for a Successful Early Childhood Workforce in New York: A New Policy Agenda" mengemukakan bahwa.

... when it comes to early childhood quality, two facts guide our work. First, young children exposed to quality early learning experiences are more likely to succeed in school and in life than their peers without those experiences. Second, teachers are at the fulcrum of successful early learning.

Pendidik PAUD sebagai seorang profesional sesuai dengan Peraturan Menteri Pendidikan Nasional RI No. 58/2009 tentang Standar PAUD harus memiliki empat kompetensi penting, sebagai berikut: Pertama, kompetensi kepribadian yang berkaitan dengan sikap dan perilaku pribadi pendidik PAUD. Kedua, kompetensi profesional yang berkaitan dengan pemahaman mengenai anak usia dini, mulai dari tahapan perkembangannya sampai dengan pemahaman tentang pemberian stimulasi terhadap pendidikan, pengasuhan, dan perlindungan pada anak usia dini. Ketiga, kompetensi pedagogik yang berkaitan dengan perencanaan kegiatan program, pelaksanaan proses pendidikan, pengasuhan, dan perlindungan, dan juga terhadap pelaksanaan penilaian pada proses dan juga hasil pada pendidikan, pengasuhan, dan perlindungan. Keempat, kompetensi sosial yang berkaitan dengan kemampuan untuk beradaptasi dengan lingkungan dan kemampuan untuk berkomunikasi secara efektif.

Dari empat kompetensi yang diharuskan dimiliki bagi pendidik PAUD sesuai dengan Permendiknas No. 58 Tahun 2009, yang menjadi pusat perhatian untuk dikembangkan adalah kompetensi pedagogik dan kompetensi profesional pendidik PAUD karena dua kompetensi lain sudah bisa dipenuhi oleh kebanyakan pendidik PAUD di Indonesia. Kompetensi profesional lebih banyak dibangun dengan cara mengikuti pendidikan akademis S-1 di bidang yang terkait dengan pendidikan anak usia dini. Adapun kompetensi pedagogik selain dengan mengikuti pendidikan akademik juga perlu dilakukan dengan berbagai pelatihanpelatihan agar kompetensi pedagogik pendidik PAUD bisa terus mutakhir sesuai dengan perkembangan keilmuan pendidikan anak usia dini.

Kompetensi pedagogik bagi pendidik PAUD sesuai dengan Permendiknas No. 58/ 2009 salah satunya adalah kemampuan untuk melaksanakan penilaian terhadap proses dan hasil pendidikan, pengasuhan, dan perlindungan. Dengan demikian, dapat disebutkan bahwa pendidik PAUD harus mampu melaksanakan penilaian secara komprehensif mulai dari pemilihan cara penilaian sampai dengan mendokumentasikan hasil penilaian tersebut dengan baik untuk kepentingan pendidikan anak usia dini. Dokumentasi hasil penilaian ini akan menjadi umpan balik bagi penyusunan program pembelajaran anak berikutnya atau dalam pembuatan individual education plan bagi 
anak-anak yang berkebutuhan khusus.

Peneliti

permasalahan

"Bagaimanakah studi kemampuan pendidik PAUD (Pendidikan Anak Usia Dini) dalam melakukan asesmen pembelajaran dan perkembangan anak usia dini di Kota Cimahi?" Melihat luasnya cakupan permasalahan, maka rumusan masalah tersebut dijabarkan dalam beberapa pertanyaan penelitian, berikut ini:

a. Bagaimana tingkat kemampuan pendidik PAUD dalam melaksanakan penilaian terhadap proses dan hasil pendidikan, pengasuhan, dan Perlindungan?

b. Apakah tingkat kemampuan pendidik PAUD kota Cimahi sudah sesuai dengan standar penilaian seperti yang tertuang dalam Peraturan Menteri Pendidikan Nasional RI Nomor 58 Tahun 2009?

Setiap anak pasti mengalami pertumbuhan dan perkembangan dalam rangkaian kehidupannya. Asesmen adalah proses mengukur sesuatu yang dibandingkan dengan sesuatu yang sudah terstandar. Sebagaimana disebutkan oleh Godwin\&Godwin (Wortham, 2005:2) menggambar asesmen atau pengukuran adalah "the process of determining, through observation or testing, an individual traits or behaviors, a program's characteristics, or the properties of some other entity, and then assigning a number, rating, or score to that determination". Asesmen dilakukan untuk mengukur pertumbuhan fisik maupun perkembangan sikap dan karakter anak.

Menurut James E Johnson (Uyu Wahyudin\&Mubiar Agustin, 2011:51) penilaian atau asesmen adalah 'in general, evaluation is the process of selecting, gathering, and interpreting information to make personal decisions or two from judgement about the worth of product or program or about of value of an approach to solve a problem or accomplish an objective'.

Penilaian adalah proses memilih, mengumpulkan, dan menafsirkan informasi untuk membuat keputusan atau untuk membuat penilaian tentang kelemahan suatu produk atau program, atau tentang sejauh mana keberhasilan pendekatan yang telah dilakukan dapat menyelesaikan masalah sehingga dapat menyempurnakan suatu sasaran/tujuan.

Tujuan penilaian menurut pendapat (Wortham, 2005:2) adalah pertama untuk mengetahui capaian perkembangan anak. Tujuan ini adalah untuk melihat kemampuan yang telah dimiliki anak pada usia tertentu. Jika orang tua ingin melihat apa saja yang sudah bisa anak lakukan, maka orang tua bisa melakukan penilaian dengan teknik observasi. Kedua, penilaian dilakukan untuk mendiagnosis. Apabila terdapat keterlambatan dalam pencapaian perkembangan anak, maka haruslah diberi treatment yang tepat untuk mengatasi masalah tersebut. Apabila penilaian dilakukan sejak dini, maka jika terdapat kegagalan dalam perkembangan akan dapat segera ditangani. Ketiga, penilaian untuk menempatkan anak pada layanan yang tepat. Anak perlu mendapatkan layanan yang tepat. Analaoginya adalah jika anak sakit panas, maka obat tepat adalah obat penurun demam panas untuk anak. Jika anak tidak belum bisa berdiri, maka berikan latihan lebih difokuskan pada kemampuan untuk berdiri. Inilah yang dikatakan layanan yang tepat sesuai dengan kebutuhan. Keempat, penilaian dilakukan dengan tujuan untuk merencanakan program. Program pada anak usia dini harus disesuaikan dengan kebutuhan anak. Anak usia 0-3 tahun akan memiliki kebutuhan yang berbeda dengan anak usia 4-6 tahun. Oleh karena itu, program pembelajaran pun akan berbeda sesuai dengan usia dan perkembangan. Program layanan yang diberikan, pada akhirnya harus dievaluasi untuk melihat tingkat efektivitasnya terhadap pertumbuhan dan perkembangan anak. 
Kelima, Penilaian anak usia dini juga dilakukan untuk tujuan lainnya. Salah satunya adalah untuk tujuan penelitian. Peneliti mengkaji anak untuk memahami perilaku mereka dengan lebih baik atau untuk mengukur kesesuaian pengalaman belajar yang diberikan bagi mereka. Penelitian dilakukan untuk melihat kesesuaian antara program pembelajaran yang diberikan dengan perkembangan anak.

Asesmen atau penilaian sangat penting dilakukan untuk mencapai pendidikan yang berkualitas bagi anak usia dini. Adapun pendidikan berkualitas adalah pendidikan yang mampu memberikan perubahan positif pada peserta didik, keluarga, dan lingkungan masyarakat. Menciptakan pendidikan berkualitas tidak terlepas dari faktorfaktor yang mendukung, seperti disebutkan oleh Wortham (2005:9) "inadequate funding, teacher shortages, teachers with inadequate training, aging schools, and poor leadership were factors that affected quality education". Dana, jumlah guru, kualitas guru, kepemimpinan, usia lembaga pendidikan adalah faktor yang berpengaruh dalam menciptakan pendidikan yang berkualitas.

Secara umum penelitian ini bertujuan memberikan informasi tentang kemampuan pendidik PAUD dalam melakukan asesmen perkembangan dan pembelajaran anak usia dini di Kota Cimahi. Adapun penelitian ini secara khusus bertujuan

a. Mengetahui tingkat kemampuan pendidik PAUD dalam melaksanakan penilaian terhadap proses dan hasil pendidikan, pengasuhan, dan perlindungan; dan

b. Mengetahui kesesuaian tingkat kemampuan pendidik PAUD kota Cimahi dengan standar penilaian seperti yang tertuang dalam Peraturan Menteri Pendidikan Nasional RI Nomor 58 Tahun 2009 yang kemudian diperbarui dengan Permendikbud No. 137 Tahun 2014.

Penelitian ini diharapkan dapat memberikan manfaat sebagai berikut:

a. Bagi para pembuat kebijakan, hasil penelitian ini diharapkan dapat memberikan wawasan tentang tingkat kemampuan pendidik PAUD dalam melakukan asesmen pembelajaran dan perkembangan pada anak usia dini sehingga dapat dijadikan dasar perencanaan peningkatan kapasitas pendidik.

b. Bagi para praktisi, penelitian ini diharapkan dapat memberikan data pemetaan riil mengenai kemampuan pendidik PAUD kota Cimahi dalam melakukan asesmen perkembangan dan pembelajaran anak usia dini sehingga dapat dijadikan masukan penyelenggaraan pendidikan PAUD.

Bagi para peneliti, penelitian ini diharapkan bermanfaat sebagai data awal yang diperlukan untuk melakukan penelitian lebih lanjut terkait asesmen terhadap perkembangan AUD.

\section{METODE PENELITIAN}

Penelitian ini menggunakan metode penelitian kualitatif yaitu pengambilan dan pengumpulan data dilakukan dengan cara observasi, wawancara, dan studi pustaka. Selain itu, dilakukan juga penyebaran kuesioner kepada para responden untuk melakukan survei tentang pemahaman dan penerapan yang mereka lakukan dalam asesmen pembelajaran dan perkembangan AUD. Selanjutnya, dilakukan analisis dan pembahasan untuk memperoleh gambaran tentang kompetensi asesmen pembelajaran dan perkembangan AUD yang menjadi profil para pendidik/guru PAUD di Kota Cimahi.

Adapun informasi yang dikumpulkan berkaitan dengan hal berikut: 1) kondisi awal subjek penelitian yaitu kompetensi asesmen pembelajaran dan perkembangan AUD para pendidik/guru PAUD di Kota Cimahi; 2) teori-teori yang 
mendukung terhadap pengembangan kompetensi asesmen; 3) dasar hukum kualifikasi pendidik/guru PAUD/TK; 4) analisis kesenjangan antara kondisi faktual kompetensi asesmen pembelajaran pendidik PAUD serta kondisi aktual yang dihadapi pendidik PAUD dalam melaksanakan tugas pembelajaran sehari-hari.

Deskripsi hasil kegiatan pengumpulan informasi, kajian teoretis serta kajian hasil penelitian lain, dan hasil penelitiaan ini dijadikan dasar untuk menganalisis guna mengungkap fakta kompetensi para pendidik/guru dalam asesmen pembelajaran dan perkembangan AUD di Kota Cimahi. Temuan dari hasil penelitian awal berdasarkan tahap kegiatan yang telah dilakukan serta tujuan yang hendak dicapai diuraikan pada bagian selanjutnya.

Penelitian ini dilaksanakan di Kota Cimahi. Subjek penelitian adalah pendidik PAUD di berbagai lembaga PAUD di Kota Cimahi. Peneliti memilih 15 lembaga PAUD yang ada di Kota Cimahi yang akan diteliti. Subjek penelitian ditentukan secara purposive sampling sebanyak 28 orang pendidik PAUD. Teknik ini diambil dengan pertimbangan tertentu sehingga 28 orang pendidik PAUD mewakili 3 kecamatan di Kota Cimahi dengan komposisi yang seimbang.

Pertimbangan peneliti menggunakan teknik purposive sampling adalah sebagai berikut: Pertama, pendidik sudah bekerja minimal 3 tahun. Kedua, pendidik PAUD tersebut bekerja pada lembaga yang sudah memiliki izin penyelenggaraan dari pemerintah setempat. Ketiga, lembaga tersebut selama ini memiliki prestasi yang baik. Keempat, lembaga tersebut direkomendasikan oleh Dinas pendidikan Kota Cimahi atau Himpaudi Kota Cimahi.

\section{HASIL PENELITIAN DAN PEMBAHASAN \\ Hasil}

Penelitian ini didasarkan pada Permendiknas No. 58 Tahun 2009 Tanggal 17 September 2009 tentang Standar Nasional Pendidikan Anak Usia Dini. Namun, seiring dilakukannya penelitian ini, telah terbit juga Permendikbud No. 137 Tahun 2014 sebagai pembaruan dari Permendiknas No. 58/2009. Permendikbud No. 137/2014 menggariskan tentang asesmen proses dan hasil pembelajaran anak mencakup a) prinsip penilaian; b) teknik dan instrumen penilaian; c) mekanisme penilaian; d) pelaksanaan penilaian; dan e) pelaporan hasil penilaian.

Proses penilaian itu dilaksanakan dengan penerapan teknik sesuai dengan tingkat pencapaian perkembangan anak melalui instrumen penilaian yang terdiri atas instrumen penilaian proses dalam bentuk catatan menyeluruh, catatan anekdot, rubrik dan/atau instrumen penilaian hasil kemampuan anak. Hasil akhir penilaian sesuai dengan Permendikbud No. 137/2014 merupakan integrasi antara berbagai teknik dan instrumen penilaian yang digunakan.

Dengan demikian, secara ideal profil pendidik atau guru PAUD/TK yang diharapkan adalah sebagai berikut.

a. Pendidik/guru memahami kelima landasan filosofis asesmen pembelajaran anak usia dini, yaitu edukatif, autentik, objektif, akuntabel, dan transparan.

b. Pendidik/guru mampu menerapkan teknik penilaian/asesmen berupa catatan menyeluruh, catatan anekdot, rubrik dan/atau instrumen penilaian hasil kemampuan anak.

c. Pendidik/guru mampu mengintegrasikan berbagai teknik asesmen tanpa harus menggunakan hanya satu bentuk asesmen pada anak usia dini.

Pertumbuhan jumlah siswa TK dari tahun ke tahun mengalami turun naik. Jumlah siswa terbesar adalah pada TK B. 
Berikut ini adalah data jumlah guru TK di Kota Cimahi 2014/2015 pada Tabel 1.

Tabel 1. Data Guru TK Menurut Jenjang Pendidkan di Kota Cimahi 2014/2015

\begin{tabular}{|c|c|c|c|c|c|c|c|c|}
\hline $\begin{array}{l}\mathbf{N} \\
\mathbf{0} \\
\cdot\end{array}$ & $\begin{array}{l}\text { Kecamata } \\
\text { n }\end{array}$ & $\begin{array}{l}\mathbf{S} \\
\mathbf{L} \\
\mathbf{T} \\
\mathbf{A}\end{array}$ & $\begin{array}{l}\text { D } \\
1\end{array}$ & D2 & D3 & $\begin{array}{l}\text { D4 } \\
\text { /S } \\
1\end{array}$ & $\begin{array}{l}\mathbf{S} \\
\mathbf{2} \\
+\end{array}$ & $\begin{array}{l}\text { Jum } \\
\text { lah }\end{array}$ \\
\hline 1 & $\begin{array}{l}\text { Cimahi } \\
\text { Selatan }\end{array}$ & $\begin{array}{l}3 \\
3\end{array}$ & $\begin{array}{l}3 \\
0\end{array}$ & $\begin{array}{l}1 \\
6\end{array}$ & 4 & $\begin{array}{l}1 \\
7\end{array}$ & - & $\begin{array}{l}1 \\
0 \\
0\end{array}$ \\
\hline $\begin{array}{l}2 \\
.\end{array}$ & $\begin{array}{l}\text { Cimahi } \\
\text { Tengah }\end{array}$ & $\begin{array}{l}4 \\
1\end{array}$ & $\begin{array}{l}3 \\
2\end{array}$ & $\begin{array}{l}1 \\
2\end{array}$ & 3 & $\begin{array}{l}3 \\
7\end{array}$ & 5 & $\begin{array}{l}1 \\
3 \\
0\end{array}$ \\
\hline $\begin{array}{l}3 \\
.\end{array}$ & $\begin{array}{l}\text { Cimahi } \\
\text { Utara }\end{array}$ & $\begin{array}{l}2 \\
5\end{array}$ & $\begin{array}{l}1 \\
3\end{array}$ & $\begin{array}{l}2 \\
1\end{array}$ & 4 & $\begin{array}{l}2 \\
8\end{array}$ & - & $\begin{array}{l}9 \\
1\end{array}$ \\
\hline \multicolumn{2}{|c|}{2014} & $\begin{array}{l}9 \\
9\end{array}$ & $\begin{array}{l}7 \\
5\end{array}$ & $\begin{array}{l}4 \\
9\end{array}$ & $\begin{array}{l}1 \\
1\end{array}$ & $\begin{array}{l}8 \\
2\end{array}$ & 5 & $\begin{array}{l}3 \\
2 \\
1 \\
\end{array}$ \\
\hline \multicolumn{2}{|c|}{2013} & $\begin{array}{l}1 \\
3 \\
6\end{array}$ & $\begin{array}{l}8 \\
8\end{array}$ & $\begin{array}{l}5 \\
8\end{array}$ & $\begin{array}{l}1 \\
4\end{array}$ & $\begin{array}{l}1 \\
1 \\
9\end{array}$ & 8 & $\begin{array}{l}4 \\
2 \\
3\end{array}$ \\
\hline \multicolumn{2}{|c|}{2012} & $\begin{array}{l}2 \\
4 \\
5\end{array}$ & $\begin{array}{l}8 \\
5\end{array}$ & $\begin{array}{l}1 \\
1 \\
0\end{array}$ & $\begin{array}{l}1 \\
8\end{array}$ & $\begin{array}{l}1 \\
3 \\
2\end{array}$ & 0 & $\begin{array}{l}5 \\
9 \\
0\end{array}$ \\
\hline \multicolumn{2}{|c|}{2011} & $\begin{array}{l}1 \\
1 \\
5\end{array}$ & $\begin{array}{l}9 \\
1\end{array}$ & $\begin{array}{l}6 \\
1\end{array}$ & $\begin{array}{l}3 \\
1\end{array}$ & $\begin{array}{l}9 \\
1\end{array}$ & 0 & $\begin{array}{l}3 \\
8 \\
9\end{array}$ \\
\hline \multicolumn{2}{|c|}{2010} & $\begin{array}{l}1 \\
1 \\
3\end{array}$ & $\begin{array}{l}8 \\
7\end{array}$ & $\begin{array}{l}7 \\
0\end{array}$ & $\begin{array}{l}1 \\
9\end{array}$ & $\begin{array}{l}5 \\
1\end{array}$ & 0 & $\begin{array}{l}3 \\
4 \\
0\end{array}$ \\
\hline \multicolumn{2}{|c|}{2009} & $\begin{array}{l}3 \\
1\end{array}$ & $\begin{array}{l}1 \\
2\end{array}$ & $\begin{array}{l}1 \\
7\end{array}$ & 6 & $\begin{array}{l}7 \\
8\end{array}$ & 1 & $\begin{array}{l}1 \\
4 \\
5 \\
\end{array}$ \\
\hline
\end{tabular}

(Sumber: BPS dan Disdikpora Cimahi)

Pada data terlihat bahwa jumlah guru yang memenuhi kualifikasi pendidikan D4/S1 cukup besar, tetapi tidak lebih besar dari jumlah guru yang berpendidikan hanya SMA. Profil pendidikan guru TK seperti ini merupakan tantangan bagi Kota Cimahi karena jenjang pendidikan SMA jauh berada di bawah standar guru TK seperti yang digariskan di dalam Permendiknas No. 58 Tahun 2009 dan yang terbaru adalah Permendikbud No. 137/2014.

Penelitian ini kemudian dikembangkan melalui penyebaran kuesioner kepada para pendidik/guru PAUD/TK. Penyebaran kuesioner dilakukan di $28 \mathrm{PAUD} / \mathrm{TK}$ di Kota Cimahi dengan melibatkan 28 orang pendidik/guru PAUD/TK, termasuk kepala sekolah sebagai responden.

Berikut ini tabel data pendidik PAUD/TK Kota Cimahi yang menjadi responden berdasarkan usia dan jenjang pendidikannya.

Tabel 2. Data Kualifikasi Akademik Guru PAUD/TK sebagai Responden Penelitian

\begin{tabular}{|c|l|l|c|c|}
\hline No. & \multicolumn{1}{|c|}{ Nama } & \multicolumn{1}{|c|}{ Lembaga Pendidikan } & Usia & $\begin{array}{c}\text { Pendidikan } \\
\text { Akhir }\end{array}$ \\
\hline 1 & Andra Kumala & Pos PAUD Aster & 51 & S1 \\
\hline 2 & Ati Aristiawati & - & 35 & S-1 \\
\hline 3 & Cucu Haryat & Pos PAUD Melati 05 & 49 & - \\
\hline 4 & Edy Susanto & Pos PAUD Melati 17 & 48 & D-3 \\
\hline 5 & Eko Wahyuningsih & Kober Kemilau Mentari & 42 & D-1 \\
\hline 6 & Elly Ruliati & Pos PAUD Mekar Sari 03 & 60 & S-1 \\
\hline 7 & Euis Setiawati & Kober Uswatun Mubarokah & 53 & SMA \\
\hline 8 & Eva Sulaeti & PP Melati 13 & 38 & - \\
\hline 9 & Kusrini & KB Sahabat Kecil & 46 & S-1 \\
\hline 10 & Maya Juridu & TPA Hati Bunda & 38 & S-2 \\
\hline 11 & Muginih & PAUD Wijaya Kusuma & 49 & S-1 \\
\hline 12 & Neneng Dariah & Kober Al Munawar & 43 & S-1 \\
\hline 13 & Neneng Munajah & TPA Cahaya Gemintang & 44 & S-1 \\
\hline 14 & Nining Suryaningsih & Pos PAUD Sri Rejeki & 48 & S-1 \\
\hline 15 & Noneng Ambiani & Kober Griya Alam & 52 & S-1 \\
\hline 16 & Nurul Rahmah & Kober Al Ikhlas Lio & 43 & S-1 \\
\hline 17 & Renih R. & TPA Ide Ananda & 41 & S-1 \\
\hline 18 & Sari Ratnaningsih & PAUD Sabillul Muttaqin & 43 & SMK \\
\hline 19 & Siti Aminah & PAUD As Sholihin & 45 & SMK \\
\hline 20 & Siti Rustini & PAUD Nurul Hidayah & 45 & S-1 \\
\hline 21 & Siti Saudah & KB Al-Azhar & 38 & SMA \\
\hline 22 & Sumanyati & PAUD Srigading & 61 & SMA \\
\hline 23 & Suprapti & TK Al Marhamah Kiducation & 48 & S-2 \\
\hline 24 & Teti Laswati & Pos PAUD Nurul Ikhlas & 44 & SMA \\
\hline 25 & Tri Agustini & PAUD Tunas Kasih & 48 & D-3 \\
\hline 26 & Yati & TK Dharma Kartini 2 & 40 & S-1 \\
\hline 27 & Yayu Rahayu & 41 & S-1 \\
\hline 28 & Yulianah Mamuaya & PP Nusa Indah 07 & & \\
\hline & & Pen Cempaka 15 & 40 & SPS \\
\hline
\end{tabular}

(Sumber: Hasil Penelitian)

Dari total responden penelitian sebanyak 28 orang terdapat guru perempuan sebanyak 27 orang dan guru laki-laki sebanyak 1 orang.

Berdasarkan data tersebut diperoleh informasi tentang profil kependidikan para pendidik/guru PAUD/TK yang menjadi responden pada Gambar 1 sebagai berikut.

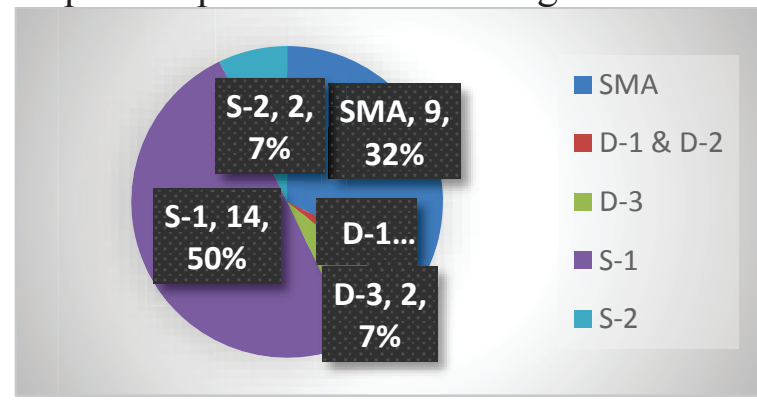

Gambar 1. Persentase Kualifikasi Akademik Guru $\mathrm{PAUD} / \mathrm{TK}$

Gambar 1 menunjukkan bahwa $35,6 \%$ pendidik PAUD/TK yang menjadi responden tidak memenuhi syarat kualifikasi akademik pendidik/guru 
PAUD/TK. Para pendidik/guru PAUD/TK tersebut hanya memenuhi kualifikasi sebagai guru pendamping atau pengasuh, sedangkan yang memenuhi kualifikasi sebagai guru inti hanya sebesar $64,4 \%$. Dengan demikian, responden yang menjadi objek penelitian ini sebagian besar telah memenuhi kualifikasi akademik sebagai guru inti di PAUD/TK.

Berdasarkan informasi dari hasil studi yang dilakukan melalui wawancara dengan unsur-unsur terkait dengan pembelajaran PAUD di Kota Cimahi diperoleh permasalahan sebagai berikut: 1) banyaknya pendidik PAUD/TK yang tidak memenuhi kualifikasi pendidik PAUD sebagaimana diamanatkan di dalam Permendiknas; 2) minimnya penyelenggaraan kegiatan peningkatan kapasitas pendidik PAUD di Kota Cimahi, terutama terkait asesmen pembelajaran AUD, baik diselenggarakan oleh pemerintah maupun oleh lembaga pendidikan sendiri; 3) kurangnya fasilitator yang berkompeten untuk memberikan materi asesmen pembelajaran dan perkembangan AUD; 4) belum optimalnya peningkatan kompetensi guru PAUD/TK yang dilakukan Disdikpora Kota Cimahi maupun organisasi profesi.

Berdasarkan gambaran umum yang telah diuraikan di atas, peneliti berasumsi kuat bahwa kompetensi para pendidik/guru PAUD/TK di Kota Cimahi dalam asesmen pembelajaran dan perkembangan AUD sebagian besar masih rendah yang tidak hanya disebabkan oleh faktor kualifikasi akademik, tetapi juga faktor-faktor lainnya yang perlu diteliti lebih lanjut.

Untuk menguji asumsi tersebut maka perlu dilakukan langkah-langkah penelitian secara kualitatif melalui pengumpulan data, pengamatan, analisis hasil data dan pengamatan, serta penarikan kesimpulan.

Peneliti mencoba menyelami fenomena bahwa terdapat fakta para pendidik/guru PAUD/TK di Kota Cimahi sebagian besar tidak memenuhi kualifikasi akademik sebagai pendidik/guru PAUD/TK di satu sisi dan di sisi lain upaya-upaya untuk meningkatkan kompetensi mereka juga masih terkendala banyak hal, terutama menyangkut biaya. Penelusuran terhadap fenomena ini untuk menemukan permasalahan utama rendahnya kemampuan kompetensi asesmen pembelajaran dan perkembangan anak usia dini bukan hanya dilihat dari faktor kualifikasi akademik, melainkan juga dari faktor pribadi (internal) pendidik/guru itu sendiri.

Berdasarkan hal tersebut melalui perangkat penelitian yang telah disediakan dan digunakan maka diperoleh temuan berikut ini.

\section{Temuan Hasil Kuesioner dan Wawancara}

Peneliti telah menyebarkan kuesioner untuk mendukung tersedianya data yaitu Kuesioner Profil Kompetensi Pendidik/Guru PAUD/TK dalam Asesmen Pembelajaran. Kuesioner disebarkan kepada 28 responden dari 28 PAUD/TK di Kota Cimahi.

Kuesioner terbagi atas topik kompetensi berikut ini: a. konsep; b. pelatihan; c. dukungan; dan d. pengembangan kapasitas.

\section{Pemahaman terhadap Konsep Kompetensi Asesmen}

Melalui kuesioner, peneliti mencari tahu apakah para pendidik/guru mengetahui dan memahami Permendikbud No. 58 Tahun 2009 tentang kompetensi Pedagogik. Dari 28 orang responden, sebanyak 25 orang menjawab bahwa mereka 'tahu' tentang kompetensi pedagogik sebagaimana termuat dalam Permendikbud No. 58 Tahun 2009. Hanya 3 orang yang menjawab 'tidak tahu'. Namun, 3 orang yang menjawab 'tidak tahu' dan 24 orang yang menjawab 'tahu' sama-sama setuju bahwa kompetensi pedagogik asesmen pembelajaran dan perkembangan AUD sangat penting untuk dikuasai. Hanya 1 orang yang menyatakan tidak penting. 
Berdasarkan pertanyaan sulit atau tidaknya asesmen pembelajaran dan perkembangan AUD dikuasai dan diterapkan di PAUD terdapat data berikut: 1) sebanyak 8 orang mengatakan kompetensi asesmen sulit dikuasai;

2) sebanyak 20 orang mengatakan kompetensi asesmen tidak sulit dikuasai;

3) sebanyak 7 orang mengatakan kompetensi asesmen sulit diterapkan;

4) sebanyak 21 orang mengatakan kompetensi asesmen tidak sulit diterapkan.

Dengan demikian, responden yang menyatakan kesulitan terhadap penguasaan dan penerapan asesmen lebih kurang $28,5 \%$. Temuan menarik dari hasil kuesioner bahwa hanya 8 orang $(28,5 \%)$ pendidik/guru yang mengaku mereka telah memahami dan menguasai asesmen pembelajaran AUD sebelum atau saat kali pertama mereka menjadi pendidik/guru PAUD/TK. Adapun sebanyak 20 orang (71,5\%) pendidik/guru sebelumnya tidak memahami dan menguasai asesmen pembelajaran AUD. Hal ini dapat dimaklumi karena sebagian besar pendidik tidak berlatar belakang pendidikan formal PAUD.

\section{Keikutsertaan dalam Pendidikan Nonformal}

Kursus atau pelatihan PAUD bersertifikat dan terakreditasi termasuk kualifikasi akademik yang dapat dipertimbangkan untuk menilai kompetensi guru PAUD/TK. Berdasarkan kuesioner yang disebarkan terkait pelatihan atau pendidikan nonformal PAUD yang secara khusus terkait asesmen pembelajaran, sebagian besar pendidik/guru telah mengikuti Pelatihan Asesmen Pembelajaran seperti data berikut ini:

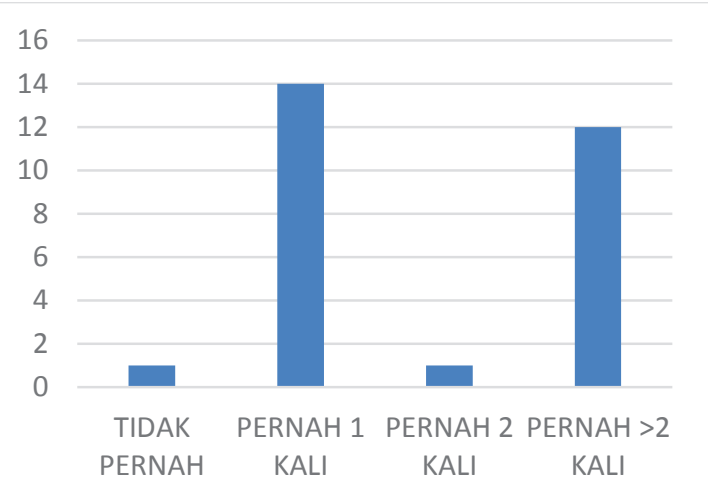

Gambar 2. Pendidik/Guru yang Pernah Mengikuti Pelatihan Asesmen Pembelajaran Anak Usia Dini 2011 s.d. 2016 di Kota Cimahi

Pelatihan asesmen tersebut diselenggarakan pada rentang tahun 2011 hingga 2016 yang diselenggarakan oleh Disdikpora Kota Cimahi, HIMAPAUDI, serta lembaga lainnya dengan durasi penyelenggaraan rata-rata 1 kali dalam setahun. Para pendidik/guru yang diteliti sebanyak $96,5 \%$ (27 orang) telah pernah mengikuti pelatihan dan 50\% (14 orang) di antaranya mengikuti hanya satu kali pelatihan. Adapun $42,8 \%$ (12 orang) pernah mengikuti pelatihan asesmen pembelajara AUD lebih dari dua kali. Sebanyak 1 orang belum pernah mengikuti pelatihan dan 1 orang telahmengikuti pelatihan sebanyak 2 kali.

Rata-rata jumlah peserta dalam pelatihan tersebut adalah 50-100 orang. Dengan demikian, dapat disebutkan bahwa pelatihan diselenggarakan dengan jumlah peserta yang terlalu besar untuk ukuran efektivitas sebuah pelatihan.

Para pendidik/guru yang mengikuti pelatihan umumnya $100 \%$ mengatakan bahwa pelatihan sangat bermanfaat bagi mereka untuk menambah wawasan dan pengetahuan. Selain itu, dari sisi pemateri atau fasilitator pelatihan, 26 orang menjawab sangat menguasai materi dan hanya 2 orang yang menyatakan bahwa pemateri tidak berkompeten atau tidak menguasai materi.

Akan tetapi, pada praktik atau penerapannya mereka tetap kesulitan karena tidak memahami teori-teori yang disampaikan disebabkan terlalu banyaknya 
ragam asesmen yang diperkenalkan. Hal tersebut wajar terjadi mengingat pelatihan diselenggarakan dengan jumlah peserta yang sangat banyak (50 s.d. 100 orang) sehingga tidak memungkinkan dilaksanakannya praktik serta tidak berlangsung secara interaktif.

\section{Kompetensi Saat ini}

Berdasarkan hasil kuesioner responden terkait penguasaan mereka terhadap asesmen pembelajaran pada saat ini diperoleh data pada Gambar 3 .

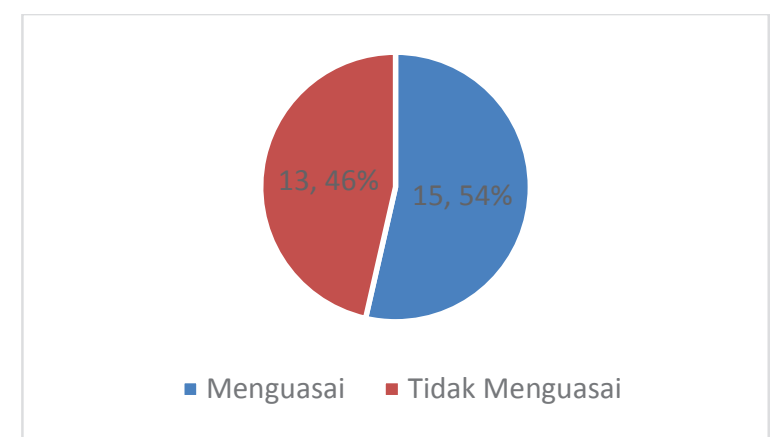

Gambar 3. Penguasaan Asesemen Pembelajaran Saat ini

(Sumber: Hasil Penelitian)

Responden yang mengaku menguasai asesmen pembelajaran sebanyak 15 orang dan mengaku tidak menguasai sebanyak 13 orang. Data ini menunjukkan hampir setengah responden ternyata belum menguasai asesmen pembelajaran dan perkembangan AUD dengan baik berdasarkan pengakuan merek. Dari 13 orang yang mengaku tidak menguasai asesmen pembelajaran dengan baik dari sisi kualifikasi pendidikan, yaitu SMA sebanyak 3 orang, D-3 sebanyak 1 orang, dan S-1 sebanyak 9 orang.

Responden yang mengaku tidak menguasai asesmen dengan baik umumnya telah pernah mengikuti pelatihan yaitu 5 orang mengikuti pelatihan asesmen pembelajaran sebanyak satu kali dan 7 orang mengikuti pelatihan asesmen pembelajaran lebih dari dua kali. Hanya 1 orang yang tidak pernah mengikuti pelatihan asesmen pembelajaran sehingga mengaku tidak mampu melakukan asesmen dengan baik.

\section{Temuan Hasil Pengamatan Pelatihan}

Peneliti juga melakukan pengamatan dan pengkajian terhadap hasil pelatihan terkait asesmen pembelajaran yang pernah diselenggarakan di Kota Cimahi. Pelatihan yang diamati terdiri atas dua pelatihan, yaitu

1) Pelatihan I pada tanggal 15-16 Agustus 2014; dan

2) Pelatihan II pada tanggal 12-13 Desember 2014.

Dari hasil pretest yang disajikan rata-rata peserta tidak mampu mencapai skor yang memadai untuk dapat memahami hakikat dan proses penilaian asesmen pembelajaran anak usia dini.

Pada pelatihan II, fasilitator memberikan kuliah teori pada hari pertama dan kedua, lalu para peserta diberi penugasan sebagai syarat untuk mendapatkan sertifikat dan mengimplementasikan pengetahuan yang telah diperolehnya selama pembelajaran. Kepada para peserta diberikan formulir asesmen pembelajaran dan perkembangan AUD yang terdiri atas 1) format observasi; 2) hasil karya; 3) catatan harian; 4) catatan anekdot; 5) format penilaian harian; dan 6) lembar kerja penetapan kompetensi dasar.

Pada akhir pelatihan, peserta diberikan materi posttest. Peningkatan pada materi posttest dibandingkan pretest tidak terjadi secara signifikan. Kesimpulan umum dari evaluasi dua penyelenggaraan pelatihan tersebut menunjukkan sedikit terjadi peningkatan pemahaman para peserta, terutama setelah mereka diberikan penugasan mandiri. Hasil praktik menunjukkan masih banyak para peserta yang kesulitan menerapkan semua teknik asesmen, terutama dalam Format Penilaian Harian (checklist) karena banyaknya poin yang harus diamati dan diisi.

Dari hasil penugasan yang dilakukan, semua peserta mengumpulkan tugas, tetapi dari segi hasil secara kualitatif masih belum dapat dikatakan memuaskan atau asesmen masih dilakukan oleh para pendidik/guru secara normatif. 


\section{Pembahasan}

Berdasarkan data yang terkumpul melalui studi pustaka, kuesioner, wawancara, pengamatan pelatihan dan pengamatan terhadap kompetensi asesmen pembelajaran serta perkembangan AUD bahwa pendidik/guru PAUD/TK di Cimahi belum memahami sepenuhnya asesmen pembelajaran dan perkembangan AUD sebagai sebuah proses yang harus direncanakan secara sistematis. Prosesproses tersebut dimulai dengan mengumpulkan data atau informasi tentang peserta didik, kemudian menganalisis, menafsirkan, dan memberikan keputusan tentang data atau informasi yang dikumpulkan sebagai proses yang berkelanjutan. Jadi, kegiatan asesmen bukanlah penilaian yang dilakukan pada akhir kegiatan atau menjelang berakhirnya masa pembelajaran tiap semester. Selanjutnya, asesmen tersebut perlu dilaporkan secara utuh dan lengkap.

Penelitian memperlihatkan bahwa kualifikasi akademik para pendidik/guru yang memenuhi syarat sesuai dengan Permendiknas No. 58/2009 tidak menjamin seorang pendidik/guru PAUD menguasai kompetensi asesmen tersebut. Demikian pula dengan pelatihan-pelatihan yang diikuti. Kesulitan pendidik/guru melakukan proses asesmen pembelajaran dan perkembangan AUD sebagaimana mestinya dipengaruhi oleh faktor beban tugas pendidik/guru, waktu yang tidak tersedia, dan juga tentunya ketidakkompetenan pendidik/guru itu sendiri. Dari beberapa teknik asesmen pembelajaran yang dikuasai para pendidik, Teknik yang paling sering digunakan adalah observasi karena dianggap lebih mudah untuk dilakukan. Adapun teknik lain yang digunakan adalah hasil karya melalui penugasan.

Dari kuesioner yang diisi para pendidik/guru sebagai responden penelitian, peneliti juga menemukan fakta yang tidak sinkron antara pengakuan mereka telah memahami dan menerapkan teknik asesemen dengan baik dan jawaban mereka terhadap teknik yang digunakan. Hal tersebut menyiratkan bahwa sebenarnya para pendidik yang mengaku telah memahami serta mampu melakukan asesmen pembelajaran dan perkembangan AUD sebenarnya belum memahami sepenuhnya dan mampu melakukannya.

Walaupun demikian, seluruh pendidik/guru menyatakan setuju bahwa kompetensi asesmen pembelajaran dan perkembangan AUD sangat penting untuk mereka kuasai. Di sisi lain terdapat juga banyak asumsi bahwa asesmen pembelajaran hanya diwujudkan ke dalam rapor yang diberikan kepada orangtua peserta didik. Asesmen pembelajaran yang dilakukan dalam bentuk catatan harian atau anekdot dari hasil pengamatan (observasi) praktis jarang atau hampir tidak pernah dilakukan oleh para pendidik/guru.

Asumsi ini juga yang melatari rendahnya pemahaman pendidik/guru terhadap berbagai teknik asesmen yang dapat mereka terapkan dan pentingnya kemampuan ini agar terus diasah mengingat tuntutan kompetensi sesuai dengan Permendiknas No. 53/2009 dan Permendikbud No. 137/2014 sangatlah tinggi. Akan tetapi, banyak guru melalui wawancara yang dilakukan peneliti bersikap apatis terhadap kegiatan peningkatan kompetensi di bidang asesmen. Sikap ini didasarkan pada pandangan berikut.

a. Anggapan bahwa pelatihan di bidang asesmen pembelajaran dan perkembangan AUD sudah terlalu sering diadakan dan materinya selalu sama.

b. Asesmen pembelajaran dan perkembangan AUD sudah mereka ketahui hanya tidak dapat mereka laksanakan karena tuntutan dan beban tugas kurikulum juga sangat berat.

c. Para orangtua AUD sebagian tidak terlalu peduli dengan laporan hasil pembelajaran dan perkembangan 
anaknya sehingga pendidik/guru juga melaksanakannya secara pragmatis.

Pada poin $\mathrm{c}$ terungkap dari kuesioner yaitu ada di antara para pendidik/guru yang mengaku bahwa orangtua kurang peduli atau tidak peduli atas laporan hasil pembelajaran dan perkembangan anaknya. Di sisi lain, seperti yang telah dijelaskan sebelumnya bahwa para pendidik/guru sering hanya menyampaikan laporan pembelajaran dan perkembangan AUD dalam rapot semester, tetapi tidak melakukannya secara kontinu dalam rentang waktu tertentu, misalnya setiap bulan.

Hal tersebut juga menunjukkan bahwa kegiatan asesmen tidak dipahami sebagai sebuah proses yang berkelanjutan serta dapat dipertanggungjawabkan terkait informasi-informasi yang dikumpulkan dan ditafsirkan oleh para pendidik/guru. Kegiatan asesmen hanya dipandang sebatas kegiatan akhir masa pembelajaran dengan memberikan laporan melalui rapor dan pendidik/guru hanya mengisikan catatan seadanya.

Dengan demikian, semestinya teknik asesmen pembelajaran dan perkembangan AUD wajib didalami oleh para pendidik/guru PAUD/TK demi menghasilkan satu penilaian yang objektif dan dapat dipertanggungjawabkan kepada orangtua peserta didik dan lembaga PAUD/TK. Hasil penelitian ini juga agar menjadi perhatian bagi Disdikpora, organisasi profesi guru PAUD/TK, dan lembaga $\mathrm{PAUD} / \mathrm{TK}$ untuk merancang program peningkatan kompetensi pendidik/guru PAUD/TK dalam asesmen pembelajaran dan perkembangan AUD.

\section{KESIMPULAN}

Kompetensi para pendidik PAUD di Kota Cimahi di bidang asesmen pembelajaran dan perkembangan anak usia dini masih rendah meskipun sebagian besar telah memiliki kualifikasi akademik yang dipersyaratkan oleh Permendiknas No. 58/2009 ataupun Permendikbud No. $137 / 2014$ serta sebagian besar pernah mengikuti pelatihan asesmen pembelajaran. Kualifikasi akademik dan pelatihan di bidang asesmen pembelajaran ternyata tidak dapat membantu peningkatan pemahaman pendidik PAUD tentang bagaimana teknik asesmen dipraktikkan setiap hari dalam proses pembelajaran. Masih banyak pendidik PAUD yang beranggapan bahwa asesmen hanya dilakukan pada saat mengisi rapor semester.

Untuk itu, Pemerintah Kota Cimahi dan lembaga PAUD/TK masih perlu meningkatkan kompetensi tersebut melalui berbagai kegiatan yang mampu menumbuhkan kesadaran akan pentingnya asesmen sekaligus meningkatkan keterampilan (skill) para pendidik dalam menerapkan teknik asesmen sesuai dengan kondisi lembaga pendidikannya. Pemahaman akan pentingnya asesmen pembelajaran dan perkembangan anak usia dini untuk memonitor tumbuh kembang anak juga perlu ditingkatkan, baik kepada lembaga PAUD/TK, pendidik PAUD, dan juga para orangtua sehingga ketiganya dapat saling bersinergi untuk mengevaluasi tumbuh kembang anak dalam segala aspek untuk menetapkan suatu pendekatan pendidikan yang tepat bagi setiap anak.

\section{UCAPAN TERIMA KASIH}

Penulis mengucapkan terima kasih kepada pihak Direktort Riset dan Pengabdian kepada Masyarakat Direktorat Jenderal Penguatan Riset dan Pengembangan Kementrian Riset, Teknologi, dan Pendidikan Tinggi yang telah mendanai penelitian ini serta pihakpihak yang telah membantu proses penelitian, yaitu Disdikpora Kota Cimahi, HIMPAUDI Kota Cimahi, dan para guru PAUD/TK yang menjadi responden. Dengan demikian, penulis berharap hasil penelitian ini dapat digunakan sebagai fondasi pengambilan kebijakan untuk meningkatkan kompetensi para pendidik PAUD, khususnya di bidang asesmen pembelajaran dan perkembangan anak usia dini. 


\section{DAFTAR PUSTAKA}

Blank et al. (2006). "Learning About the Learners: An Examination of Training for Early Care and Education Workers in New York City". NYC Early childhood professional development institute. diakses pada Desember 2014.

http://earlychildhoodnyc.org/pdfs/ eng/needs\%20assessment.pdf.

Essa, E.L. (2003). Introduction to Early Childhood Education (Fourth edition). Canada: Delmar Learning.

Ghony, M., Djunaidi \& Fauzan, A. (2012). Metode Penelitian Kualitatif. Yogyakarta: Ar-Ruzz Media.

Novianti, R., dkk. (2013). "Pemetaan Kemampuan Guru PAUD Dalam Melaksanakan Asesmen Perkembangan Anak Usia Dini Di Kota Pekanbaru". dalam Jurnal Sorot Vol 8 No 1. Pekanbaru: Lembaga Penelitian Universitas Riau.

Preston et al. (2012). “Aboriginal Early Childhood Education in Canada: Issues of Context". Journal of Early Childhood Research. Volume 10 Number 1.

Sugiyono. (2013). Metode Penelitian Kuantitatif, Kualitatif, Dan R\&D. Bandung: Alfabeta.

Suyadi, Ulfah, dan Maulidya. (2013). Konsep Dasar PAUD. Bandung: Rosdakarya.

Ochson, S. and Sobel, K. (2009). "Improving the Quality of Early Childhood Education Through
System Building". NYC Early Childhood Professional Development Institute diakses pada Desember 2014. Vol II, No. 1. $<$ www.earlychildhoodnyc.org/pdfs /policy\%20Brief\%202_1.pdf $>$.

Suyadi. (2016). "Perencanaan dan Asesmen Perkembangan Pada Anak Usia Dini (Studi kasus pada Lembaga Pendidikan Anak Usia Dini (PAUD/TK/RA) di Daerah Istimewa Yogyakarta)" dalam Golden Age Jurnal Ilmiah Tumbuh Kembang Anak Usia Dini, Vol. 1 No. 1 April 2016.

Tarrant, Kathleen. (2013). Building the Pipeline for a successful Early Childhood Workforce in New York:A New Policy Agenda. New York Early Childhood Professional Development Institute. diakses pada Desember 2014. $<$ http://earlychildhoodnyc.org/pdfs/ policy $\% 20 \%$ Brief $\% 202013$.pdf $>$.

Wahyudin, U \& Agustin, M. (2011). Penilaian Perkembangan Anak Usia Dini. Bandung: Refika Aditama.

Wortham, S. C. (2005). Assessment in Early Childhood Education. New Jersey: Pearson.

---. (2006). Early Childhood Curriculum. New Jersey: Pearson.

Yulindrasari, Hani. (2011). Peningkatan Kompetensi Profesional Guru PAUD Non Formal Melalui Pelatihan PAUD Berbasis Active Learning.

Sujiono, Y.N. (2009). “Asesmen Perkembangan Anak Berbasis Kecerdasan Jamak". Makalah Semiloka PAUD. Bandung: Direktorat PAUD. 